\title{
Bioaerosols at plants processing materials of plant origin-a review
}

\author{
Karol Bulski ${ }^{1}$
}

Received: 24 January 2020 / Accepted: 29 April 2020 / Published online: 15 May 2020

(C) The Author(s) 2020

\begin{abstract}
Due to the dynamic development of industry, related to the processing of plant materials and a subsequent significant increase in the number of employees working in this kind of industry, the indoor air quality is of great importance for the human health. The premises of plants processing plant materials are a specific environment, related to exposure to biological agents. The major sources of microbial contamination of premises are employees' activities and the operation of devices used in the production process, quality of plant materials, technological processes, construction materials, ventilation (air-conditioning) systems, and outdoor air. Biological agents (primarily bacteria and fungi) transported in the air can cause numerous adverse health outcomes in exposed workers.
\end{abstract}

Keywords Bioaerosols $\cdot$ Bacteria $\cdot$ Fungi $\cdot$ Processing plants $\cdot$ Materials of plant origin

\section{Introduction}

The increase in interest in plant materials' products results in a steady increase in employment in the industry, related to the processing of plant materials. This is due to the fact that plant raw materials are increasingly used in many industries, from food processing to cosmetology or medicine. In recent years, attention has increasingly been drawn to the fact that employees of plants processing materials of plant origin may be exposed to many harmful factors. These factors are chemical and biological pollution, mechanical vibrations, noise, electromagnetic fields, lighting, static electricity, and variable microclimate. Due to the fact that the production rooms are a specific environment, the concerns expressed by employees are related to exposure to biological aerosols. This is due to the fact that we still do not know enough about the relationship between the exposure to bioaerosols and adverse health effects. There is a lack of global generally accepted limit values of concentration of bioaerosols and methodological recommendations, related to the control of these kinds of threats. In the indoor

Responsible editor: Diane Purchase

Karol Bulski

karol.bulski@urk.edu.pl

1 Department of Microbiology and Biomonitoring, University of Agriculture in Krakow, Krakow, Poland air of plants processing plant materials, any microbiological agent present in the air is undesirable and can be considered as a contaminant. In this type of plant, it is primarily bacteria, microscopic fungi, viruses, plant pollen, seeds, and products produced by microorganisms, e.g., endotoxins, glucans, fungal metabolites and allergens, enzymes. These particles (suspended in the air) are present usually in low concentrations, so they do not pose a threat to the humans (their presence can be considered as natural). The problem of the contamination may appear when the level of microbial contaminants in the air rises above a certain limit, which is considered as a natural background for the environment.

Microbiological contamination of indoor air may result from microbial emissions in the room or may come from the external environment. Bioaerosols' levels usually increase when rooms are occupied and humans have been reported to be a source of microorganisms in settled dust samples (Adams et al. 2015; Bragoszewska 2019). In industry, an additional source of biological aerosol can be production and processing (Kim et al. 2018). Unfortunately, individual exposure levels and susceptibilities are highly variable. That is why an inhalation dose has not yet been specified. It is difficult to characterize the actual risk to workers from exposure to biological aerosols resulting from their work activities (Bragoszewska and Biedron 2018). Nowadays, more research is needed to precisely describe the role of biological aerosols in the initiation or development of diverse symptoms and human diseases (Jiayu et al. 2019). 
The author decided to prepare a review paper, which is a kind of summary and describing the environmental problem of bioaerosol in plants processing raw materials of plant origin, including possible sources of biological aerosols in this type of workplace and their potential impact on the worker's health.

\section{Bioaerosol—definition and characteristics}

As defined, the term "bioaerosol" or "biological aerosol" means a collection of biological particles dispersed in air or another gas phase. Bioaerosol particles can be (Górny 2010; Bragoszewska et al. 2018; Ławer 2019) as follows:

a) Single spores of microorganisms, pollen, bacterial vegetative cells, and viruses;

b) Aggregates composed of several spores of microorganisms or bacterial vegetative cells;

c) Aggregates formed by several spores of microorganisms or bacterial vegetative cells with other biological material (e.g., mammalian allergens);

d) Products of microbial origin, fragments of bacterial cells, or fungal spores (e.g., endotoxins, mycotoxins);

e) Multigrain structures composed of non-biological particles transporting material of biological origin (e.g., endotoxin particles connected with granular aerosol particles).

The composition, size, or population of microorganisms forming bioaerosol depends on the source, dispersion mechanisms in the air, and environmental factors, such as the type of organism, viability, growth chase, and resistance to electromagnetic radiation (Niemiec and Zamorska 2002; Kaiser and Wolski 2007; Nourian et al. 2007).

Biological aerosols are omnipresent in the natural environment. Biological particles can be released into the air from almost any natural or artificial surface. Bacteria and fungi can get into the atmosphere as a result of their removal from plant and soil surfaces, due to the wind or thermal convection processes, and after spontaneous or rain forced emissions from natural water reservoirs. The human activity also has a big impact on the qualitative and quantitative composition of the biological aerosol. The quantitative and qualitative diversity of microorganisms in the air and their distribution in different regions of the world may result from differences in the density and size of the human population and industrial activity (Redford and Fierer 2009; Heo et al. 2010; Bowers et al. 2012; Polymenakou 2012).

The range of aerodynamic diameters of bioaerosol particle sizes from nanometric (e.g., bacterial endotoxins, $30-50 \mathrm{~nm}$ ), through submicron (e.g., fragments of bacterial or fungal cells), to particles whose diameter can reach from several dozen to over $100 \mu \mathrm{m}$. The biological fraction of bioaerosols in the atmosphere consists of pollen $(17-58 \mu \mathrm{m})$, fungal spores $(1-30 \mu \mathrm{m})$, bacteria $(0.25-8 \mu \mathrm{m})$, viruses $(<0.3 \mu \mathrm{m})$, and plant and animal fragments, representing 10 to $30 \%$ of the volume of all suspensions in this environment. Bacteria in the air are most often attached to organic or inorganic particles ranging in size from $\leq 0.65$ to $\geq 7.0 \mu \mathrm{m}$, with an average particle size $\geq 2.1 \mu \mathrm{m}$ in diameter. On the other hand, fungi usually have a size below $10 \mu \mathrm{m}$ (Grajewski and Twarużek 2004; Błaszczyk 2010; Estillore et al. 2016; MazurkiewiczZapałowicz et al. 2016).

Microorganisms that are part of bioaerosols cannot grow during airborne transport - they are only able to survive in the air for some time. It depend on their properties and environmental conditions. This is influenced by the nature of the environment (access to nutrients, physical, and chemical factors of environmental stress) and the individual characteristics of microorganisms, including the particle size of bioaerosols (Pillai and Ricke 2002; Kaiser and Wolski 2007; Nourian et al. 2007; Menetrez et al. 2010; Puspita et al. 2012). The small components of bioaerosol retain their viability in the environment longer than larger microorganisms. Live persistent forms (e.g., bacterial endospores) can survive in the air for a long time, and the most sensitive, vegetative forms die quickly (Table 1). Due to the relatively small size of the cell, the most adapted forms of microorganisms are cocci and bacteria whose cells are covered with a layer of mucus or produce yellow and red carotenoid dyes that protect them from harmful UV radiation (Gotkowska-Płachta et al. 2008; Gatchalian et al. 2010; Barabasz et al. 2011; Galperin and Yutin 2013).

\section{The impact of bioaerosol on the human health}

Under normal environmental conditions, at low bioaerosol concentrations, most microorganisms do not pose a health risk. Unfortunately, some of them may be pathogenic, allergic, or toxic. Microbiological aerosols are of the greatest epidemiological importance (Górny 2019). Their presence in the environment can lead to adverse health effects in people, from

Table 1 The survival time of selected bioaerosol components in the air (Górny 2004)

\begin{tabular}{ll}
\hline Microorganism & Survival time in the air \\
\hline Aspergillus, Penicillium & Over 12 years \\
Mite allergens & Decay within a few months \\
Flu viruses & Up to 3 weeks \\
Escherichia coli & Dies within 30-60 min \\
Streptococcus faecalis & Dies within 30-60 min \\
Legionella pneumophila & Up to 15 min \\
\hline
\end{tabular}


simple irritation, through allergic reactions, to the occurrence of infections or toxic reactions. The health effect caused by inhalation of various types of biological particles depends mainly on their size, chemical composition, microbiological properties, and the place of their deposition in the respiratory system. It is associated with many diseases of social significance, especially respiratory diseases (Flannigan and Miller 1994; Douwes et al. 2003; Sykes et al. 2007; Roy and Reed 2012; Walser et al. 2015; Górny 2019). The threat from biological factors is associated with the performance of a specific profession and the presence or properties of each factor (Dutkiewicz and Górny 2002; Dutkiewicz 2004; Nguyen et al. 2017). Diseases whose etiological factors are transmitted by the air include the following (Chmiel et al. 2015; Ebisz et al. 2016; Prażak and Kowalska 2017):

a) Viral: chickenpox, influenza, mononucleosis, rubella, mumps (parotitis), and shingles, meningitis;

b) Bacterial: bronchitis and pneumonia, rhinitis and bronchitis; pulmonary tuberculosis, diphtheria, whooping cough, and sclerosis;

c) Fungal: lung aspergillosis, lung mucormicosis, lung cryptococcosis, bronchial mycosis, lung geotrychosis, fungal pneumonia, pleural mycosis, and others.

It is important that the dispersion of the plant, animal, and human pathogens and allergens has serious implications for agriculture and public health (Fröhlich-Nowoisky et al. 2016). Threats resulting from the presence of microorganisms in the air are not only limited to impact on the health of exposed persons (viral, bacterial, fungal, allergic diseases, poisoning with endotoxins and mycotoxins), but also to microbial contamination of products produced in the industry (food, pharmaceutical, cosmetics) and agriculture (crop production, animal production) (Chmiel et al. 2015). The threat is caused not only by the presence of pathogenic microorganisms or toxins in the air, but also by an excessive number of saprophytic microorganisms, especially if their composition is not diversified (Cabral 2010; Gładysz et al. 2010). Harmful microbiological agents can enter the human body by inhalation, direct contact (through the damaged skin or mucous membranes), or by ingestion. Erogenous route and the inhalation of bioaerosol with a high concentration of microorganisms, toxins, or allergens are of paramount importance in the spread of harmful biological agents in the work environment. The digestive tract is not typical for occupational infections (Dutkiewicz and Jabłoński 1989; Mazurkiewicz-Zapałowicz et al. 2016).

The point of the theoretical maximum penetration depth, i.e., how deep in the respiratory system the particle will reach, depends on the aerodynamic diameter of microorganisms. Bioaerosol particles with an aerodynamic diameter (Górny 2019): a) Below $0.65 \mu \mathrm{m}$ reach the alveoli region;

b) $0.65-1.1 \mu \mathrm{m}$ reach the pulmonary bronchioles area;

c) $1.1-2.1 \mu \mathrm{m}$ reach the end bronchioles area;

d) 2.1-3.3 $\mu \mathrm{m}$ reach the secondary bronchial area;

e) $3.3-4.7 \mu \mathrm{m}$ reach the region of the trachea and primary bronchi;

f) $4.7-7.0 \mu \mathrm{m}$ reach the throat region;

g) $7.0-11.0 \mu \mathrm{m}$ reach the nasal passages;

h) Above $11.0 \mu \mathrm{m}$ practically do not penetrate deep into the respiratory system.

Also, allergies can be one of the diseases caused by biological factors. About 100 species of fungi are associated with the symptoms of allergic respiratory diseases. These are usually species such as Penicillium notatum, Aspergillus fumigatus, or Cladosporium herbarum (Fischer and Dott 2003; Helbling and Reimers 2003; Mazurkiewicz-Zapałowicz et al. 2016; Lang-Yona et al. 2016). At low concentrations in bioaerosol, most of the bacteria do not pose a threat to human health, but some of them may exhibit allergenic properties. Bacterial endotoxins and (1-3)- $\beta$-D-glucans of fungal origin, found in bioaerosol, may cause upper respiratory tract inflammation, flu-like symptoms, or bronchial asthma (Krajewski et al. 2000; Nielsen et al. 2000; Niemiec and Zamorska 2002; Cyprowski 2007; Ławniczek-Wałczyk and Górny 2010; Gołofit-Szymczak and Górny 2017). The previous analysis of the results showed that in residential, school, and office environments, the mean endotoxin loads in settled floor dust varied between 660 and $107.000 \mathrm{EU} \mathrm{m}^{-2}, 2180$ and 48.000 $\mathrm{EU} \mathrm{m}^{-2}$, and 2700 and $12.890 \mathrm{EU} \mathrm{m}^{-2}$, respectively (Salonen et al. 2016).

In industry, the workers often do not have knowledge about health hazards in their work, ignoring the wearing of protective clothes, so there could be a risk to their safety and health (Bragoszewska 2019).

\section{Bioaerosols in the premises of plants processing materials of plant origin}

The main source of biological particles in indoor air are living organisms: people, animals, plants, and materials collected in buildings or external air penetrating the rooms (Pasanen and Kasanen 2000; Gołofit-Szymczak et al. 2013; Chmiel et al. 2015; Małecka-Adamowicz et al. 2019). Analyses carried out in various countries indicate that in most cases, the concentration of microbiological contaminants in the indoor air is higher than in the outdoor environment (Bragoszewska et al. 2020; Li et al. 2020). Also, the quantitative and qualitative composition of bioaerosol in various types of interiors is more stable. This is especially important because we spend more and more time indoors. It is estimated that people spend between $80 \%$ and $95 \%$ of their time in an indoor environment 
during their lifetime. An adult performs approx. 20-22 thousand breaths per day, breathing in over $10 \mathrm{~m}^{3}$ of air with pollutants (Dacarro et al. 2003; Cabral 2010). There are a lot of studies that investigated human-to-human transmission via expiratory droplets in indoor environments with a view to minimizing it, but we have to remeber that there are also other airborne pathways that can transmit microorganisms (Lai et al. 2018).

In the industrial environment, the upmost impact on the bioaerosol concentrations have employees' activities and the operations of using devices. This may cause air movement and release the biological particles during the production process. An important source of microorganisms in the industrial work environment are technological processes such as wastewater treatment, waste collection and processing, and biomass extraction and processing (Bawiec et al. 2016; Vantarakis et al. 2016; Patil and Kamble 2017; Han et al. 2018; Paśmionka 2020). In urban waste water, apart from typically environmental microorganisms, there may also be pathogenic species from the genera Streptococcus, Helicobacter, Legionella, or Salmonella. These microorganisms can be released into the air and pose a serious threat to workers' health. Gram-negative enterobacteria from the Enterobacteriaceae family, Grampositive cocci, and staphylococci are extremely important. Bacterial endotoxin, produced by Gram-negative rods from the Enterobacteriaceae family, may pose a significant threat to worker's health during biomass processing. Also, during large-scale biomass, burning emissions has implications for endotoxin exposure on human health (Rajput et al. 2017; Wei et al. 2019). Mold fungi of the genera Aspergillus, Penicillium, Alternaria, Scopulariopsis, and Trichoderma as well as mesophilic and thermophilic actinobacteria may be present in organic dust as a result of biomass processing (Kalogerakis et al. 2005; Buczyńska et al. 2007; Ziajka 2008; Chen and Hildemann 2009; Gołofit-Szymczak and Ławniczek-Wałczyk 2011). It should be emphasized that mycological pollution of both indoor and outdoor air is correlated with the concentration of dust in the air of buildings (Grzyb and Lenart-Boroń 2020).

The air quality at the production areas of plants processing plants depends primarily on the type and microbiological purity of processed materials of plant origin. Microbiologically contaminated plant materials (e.g., cereals or herbs) can contribute to the deterioration of air quality in halls and warehouses (places of processing and packaging). In $25 \%$ of cases, plant materials are responsible for microbial pollution of the air (Ziajka 2008). Soil has a significant impact on the microbiota of plant materials - habitat for all groups of microorganisms, represented by aerobes and anaerobes, as well as vegetative and spore forms. The largest microbiological contamination of soil is observed in the surface layer. During cultivation, harvesting, storage, and processing of grain employees may be exposed to harmful bioaerosol. Grain ripening in spikes or harvesting and stored in large quantities with high humidity, subjected to mechanical damage (from aggressive harvesting technique and machine threshing), is a very good substrate for the growth of mold fungi. Machine processing of grain can generate very large amounts of organic dust, which is an important risk factor for employees of plant processing plants (Soroka et al. 2008; Juszczak 2011).

Several dozens of bacterial species can occur in the air of the premises of plants processing plant materials. Grampositive cocci from the Staphylococcus and Streptococcus genera, and Gram-negative bacteria (Pantoea, Alcaligenes, Acinetobacter), which occur on the surface of many plants (e.g., on cereal grains) can predominate in indoor air. Also, actinobacteria (Streptomyces, Thermoactinomyces) and mold fungi may be present in the air, especially predominate genera such as Aspergillus, Penicillium, and Alternaria (Dutkiewicz and Mołocznik 1998). The composition of the air microbiota can be different. It depends (like the concentration of microorganisms) on the number of employees, the impact of the external environment, pollution of plant raw materials, and microclimatic conditions. At one plant processing plants, the number and type of microorganisms in the air can be diverse in each production hall and warehouse (Gutarowska and Piotrowska 2007; Bulski et al. 2017). The microbiological quality of the air in this type of interior may change during the production cycle, depending on the activity of employees and the operation of production machines (Jakubczyk 1999). Receiving and unloading plant materials provided by the supplier, drying excessively moist material, weighing, screening cereal grains, preparing a plant mix, or packaging the finished product may have particular relevance. These activities are related to release the organic dust into the air. The most harmful biological factors occurring in organic dusts (e.g., from cereals or hay) include bacteria and fungi, as well as the allergenic and immunotoxic substances (endotoxins, glucans, mycotoxins) (Gwo-Hwa and Chih-Shan 1999; Wołejko et al. 2016).

An important factor that affects microbial air pollution in industrial environment is hygienic and sanitary rooms condition. The presence of organic dust during production, deposition of pollutions in the crevices of the floor or walls, the growth and presence of fungi on building constructions or equipment in production halls, and the development of biofilm on production surfaces, devices, machines, or tools are examples of "hygienic neglect" in processing plants. It contribute to the increase in the number of microorganisms in the air of the internal environment (Gutarowska and Piotrowska 2007). Also, secondary sources, which are extremely difficult to reveal and detect, can significantly affect the maintenance of adequate air hygiene in the production environment. Frequently contaminated and neglected ventilation or air conditioning systems can also be a source of microorganisms spreading in the air of production halls (Kołożyn-Krajewska 
2001; Gutarowska and Piotrowska 2007). The exposure to harmful biological agents may change depending on the indoor construction and equipment, ventilation system and air movement, occupant density and activity, and cleaning procedures (Kozdrój et al. 2019). Additionally, aerobiologists and building scientists should cooperate to determine how building characteristics and features (e.g., air-exchange rate, ventilation process) influence indoor biological aerosol concentrations (Prussin et al. 2015).

In plants processing materials of plant origin, fungi constitute a separate problem. This is due to the specifics of production - when the plant materials (e.g., cereals or herbs) are processed, the air inside the halls can be dry or dusty. In these circumstances, xerophilic molds may occur, especially species from the genera Alternaria, Cladosporium, Penicillium, Aspergillus, Rhizopus, and Mucor are the most frequently represented. It may be the most important cause of allergies (Pastuszka et al. 2000; Obtułowicz 2001; Piotrowska et al. 2001; Górny and Dutkiewicz 2002; Herbarth et al. 2003; Stryjakowska-Sekulska et al. 2007; Simon and Duquenne 2014). In conclusion, the workplace safety of plants processing materials of plant origin is dependent on understanding and controlling of the production or packaging process and other operations that can lead to the generation and dispersion of biological aerosols in the air (Mirskaya and Agranovski 2018).

\section{Harmful biological agents-acceptable concentrations in the work environment}

The quantitative interpretation of the results of bioaerosol measurements in the indoor environment is difficult. This is due to the lack of universally acceptable hygiene standards for harmful biological agents. The main reason for this situation is the inability to determine the close correlation between the dose of a harmful biological agent and the health effect. In addition, the immunity of the human body is an individual mark. However, in Poland, the Polish Panel of Experts of Biological Factors presented the recommended values of permissible concentrations of harmful biological agents in the work environment (Table 2). These values were determined by repeated measurements of harmful biological agents concentrations. It allows to assess the degree of pollution of the studied environment and determine what is "typical and acceptable," and what is "unusual and unacceptable."

Until now, microbiological analyses of air showed that the concentrations of bacterial and fungal aerosols in plants processing plant materials usually range from $10^{3}$ to $10^{6} \mathrm{cfu} \mathrm{m}^{-3}$ (Jain 2000; Dutkiewicz et al. 2000, 2001; Dutkiewicz 2005; Góra et al. 2004; Krysińska-Traczyk et al. 2005; Skórska et al. 2005; Tsapko et al. 2015; Aringoli et al. 2012). The activity like processing agricultural products (grain, hay, herbs) can be responsible for worker's exposure to viable microorganisms or their fragments and metabolites. High levels of exposure to bioaerosols were detected for sawmill workers and during vegetable or fruit processing (Mayer et al. 2016; Bulski et al. 2017; Mirskaya and Agranovski 2018). Reeb-Whitaker and Bonauto (2014) indicate that occupational exposure to hop dust causes respiratory diseases in workers involved in all phases of the hop harvest and processing. Douwes et al. (2003) pay attention to studies describing a potential exposure to asthmatic diseases in workers during potato processing. Composting of organic waste also can generate bioaerosols which have been associated with a range of acute and chronic adverse health effects and diseases (Robertson et al. 2019).

\section{Summary}

In recent years, biological factors are becoming a serious problem of occupational medicine and public health. Employees working in plants processing plant materials should be informed of possible health hazards arising from inhalation of polluted air. Preventive measures should be identified, through appropriate room architecture and technical
Table 2 Proposals for acceptable concentrations of microorganisms in the air according to the Polish Panel of Experts of Biological Factors (Augustyńska and Pośniak 2016)

\begin{tabular}{lll}
\hline Microbiological factor & Permissible concentration \\
\cline { 2 - 3 } & $\begin{array}{l}\text { Working spaces contaminated by organic } \\
\text { dust }\end{array}$ & $\begin{array}{l}\text { Living quarters and public } \\
\text { buildings }\end{array}$ \\
\hline $\begin{array}{l}\text { Mesophilic bacteria } \\
\text { Gram-negative bacteria }\end{array}$ & $1.0 \times 10^{5} \mathrm{cfu} \mathrm{m}^{-3 *}$ & $5.0 \times 10^{3} \mathrm{cfu} \mathrm{m}^{-3}$ \\
$\begin{array}{l}\text { Thermophilic } \\
\begin{array}{l}\text { actinobacteria } \\
\text { Fungi }\end{array}\end{array}$ & $2.0 \times 10^{4} \mathrm{cfu} \mathrm{m}^{-3 *}$ & $2.0 \times 10^{2} \mathrm{cfu} \mathrm{m}^{-3}$ \\
Bacterial endotoxin & $2.0 \times 10^{4} \mathrm{cfu} \mathrm{m}^{-3 *}$ & $2.0 \times 10^{2} \mathrm{cfu} \mathrm{m}^{-3}$ \\
\hline
\end{tabular}

$c f u$ colony-forming units, $E U$ endotoxic unit

*For respirable fraction, the proposed values should be halved 
equipment, because it can reduce workers' exposure to harmful biological agents. In environment of plants processing plant materials, it is necessary to monitor microclimatic conditions in production rooms. Correctly designed, efficient, and regularly monitored in terms of hygienic quality ventilation is also equally important.

Open Access This article is licensed under a Creative Commons Attribution 4.0 International License, which permits use, sharing, adaptation, distribution and reproduction in any medium or format, as long as you give appropriate credit to the original author(s) and the source, provide a link to the Creative Commons licence, and indicate if changes were made. The images or other third party material in this article are included in the article's Creative Commons licence, unless indicated otherwise in a credit line to the material. If material is not included in the article's Creative Commons licence and your intended use is not permitted by statutory regulation or exceeds the permitted use, you will need to obtain permission directly from the copyright holder. To view a copy of this licence, visit http://creativecommons.org/licenses/by/4.0/.

\section{References}

Adams RI, Bhangar S, Pasut W, Arens EA, Taylor JW, Lindow SE, Nazaroff WW, Bruns TD (2015) Chamber bioaerosol study: outdoor air and human occupants as sources of indoor airborne microbes. PLoS ONE 10(5):e0128022

Aringoli EE, Cambiagno DE, Chiericatti CA, Basilico JC, Basilico MLZ (2012) Mycoflora study in a wheat flour mill of Argentina. Braz J Microbiol 43(4):1444-1451

Augustyńska D, Pośniak M (2016) Harmful factors in the working environment-limit values. Interdepartmental Commission for Maximum Admissible Concentrations and Intensities for Agents Harmful to Health in the Working Environment: CIOP-PIB (in Polish)

Barabasz W, Borla A, Galus-Barchan A, Szmigiel A (2011) Landfill as a source of microorganisms harmful to health. In: Municipal Waste Management, Committee of Analytical Chemistry of the Polish Academy of Sciences. Feniks, Koszalin, pp 5-17 (in Polish)

Bawiec AJ, Pawęska K, Jarząb A (2016) Changes in the microbial composition of municipal wastewater treated in biological processes. $\mathrm{J}$ Ecol Eng 17(3):41-46

Błaszczyk MK (2010) Environmental microbiology. PWN, Warszawa (in Polish)

Bowers RM, McCubbin IB, Hallar AG, Fierer N (2012) Seasonal variability in airborne bacterial communities at a high-elevation site. Atmos Environ 50:41-49

Bragoszewska E (2019) Exposure to bacterial and fungal aerosols: microorganism indices in a waste-sorting plant in Poland. Int J Environ Res Public Health 16. https://doi.org/10.3390/ijerph16183308

Bragoszewska E, Biedroń I (2018) Indoor air quality and potential health risk impacts of exposure to antibiotic resistant bacteria in an office rooms in Southern Poland. Int J Environ Res Public Health 15. https://doi.org/10.3390/ijerph15112604

Brągoszewska E, Biedroń I, Kozielska B, Pastuszka JS (2018) Microbiological indoor air quality in an office building in Gliwice, Poland: analysis of the case study. Air Qual Atmos Health 11:729 740

Bragoszewska E, Palmowska A, Biedroń I (2020) Investigation of indoor air quality in the ventilated ice rink arena. Atmos Pollut Res 11:903 908. https://doi.org/10.1016/j.apr.2020.02.002
Buczyńska A, Cyprowski M, Piotrowska M, Szadkowska-Stańczyk I (2007) Indoor moulds: results of the environmental study in office rooms. Med Pr 58:521-525 (in Polish)

Bulski K, Ostafin M, Frączek K, Chmiel MJ, Suprovych T, Pustova Z (2017) The microbiological air quality at the fruit and vegetable processing facility. Scientific achievements in agricultural engineering, agronomy and veterinary medicine, Traicon, ISBN 978-8365180-17-9, 54-64

Cabral JPS (2010) Can we use indoor fungi as bioindicators of indoor air quality? Historical perspectives and open questions. Sci Total Environ 408:4285-4295

Chen Q, Hildemann LM (2009) The effects of human activities on exposure to particulate matter and bioaerosols in residential homes. Environ Sci Technol 43:4641-4646

Chmiel MJ, Frączek K, Grzyb J (2015) The problems of microbiological air contamination monitoring. Water Environ Rural Areas 1(49):1727 (in Polish)

Cyprowski M (2007) Harmful biological agents and assessment of their occurrence during working with municipal waste. In: Hazards and health effects of exposure to harmful biological agents of waste management employees. Nofer Institute of Occupational Medicine, Łódź, pp 21-40 (in Polish)

Dacarro C, Picco AM, Grisoli P, Rodolfi M (2003) Determination of aerial microbiological contamination in scholastic sports environments. J Appl Microbiol 95(5):904-912

Douwes J, Thorne P, Pearce N, Heederik D (2003) Bioaerosol health effects and exposure assessment: progress and prospects. Ann Occup Hyg 47:187-200

Dutkiewicz J (2004) Occupational biohazards: current issues. Med Pr 55(1):31-40 (in Polish)

Dutkiewicz J (2005) Exposure of Indian agricultural workers to airborne microorganisms, dust and endotoxin during handling of various plant products. Ann Agric Environ Med 12:268-275

Dutkiewicz J, Górny RL (2002) Biological factors hazardous to human health: classification and criteria of exposure assessment. Med $\mathrm{Pr}$ 53:29-39 (in Polish)

Dutkiewicz J, Jabłoński L (1989) Biological occupational harmfulness. PZWL, Warszawa (in Polish)

Dutkiewicz J, Mołocznik A (1998) Organic dusts of plant and animal origin. Documentation of the proposed occupational exposure limit values Principles and Methods of Assessing the Working Environment 18:151-183 (in Polish)

Dutkiewicz J, Krysińska-Traczyk E, Skórska CZ, Sitkowska J, Prażmo Z, Urbanowicz B (2000) Exposure of agricultural workers to airborne microorganisms and endotoxin during handling of various vegetable products. Aerobiologia 16:193-198

Dutkiewicz J, Krysińska-Traczyk E, Prażmo Z, Skórska C, Sitkowska J (2001) Exposure to airborne microorganisms in Polish sawmills. Ann Agric Environ Med 8(1):71-80

Ebisz M, Król K, Lar K, Mroczek A, Zbrojkiewicz E, Kopciak M, Złotkowska R (2016) The health risk due to exposure to bioaerosol occurring in health care institutions. Environ Med 19(2):55-62 (in Polish)

Estillore AD, Trueblood JV, Grassian VH (2016) Atmospheric chemistry of bioaerosols: heterogeneous and multiphase reactions with atmospheric oxidants and other trace gases. Chem Sci 7:6604-6616

Fischer G, Dott W (2003) Relevance of airborne fungi and their secondary metabolites for environmental, occupational and indoor hygiene. Arch Microbiol 179:750-782

Flannigan B, Miller JD (1994) Health implications of fungi in indoor environments - an overview. In: Health implications of fungi in indoor environments. Elsevier, Amsterdam, pp 3-28

Fröhlich-Nowoisky J, Kampf CJ, Weber B, Huffman JA, Pöhlker C, Andreae MO, Lang-Yona N, Burrows SM, Gunthe SS, Elbert W, Su H, Hoor P, Thines E, Hoffmann T, Després VR, Pöschl U (2016) 
Bioaerosols in the Earth system: climate, health, and ecosystem interactions. Atmos Res 182:346-376

Galperin MY, Yutin N (2013) A genomic update on clostridial phylogeny: Gram-negative spore formers and other misplaced clostridia. Environ Microbiol 15(10):2631-2641

Gatchalian NG, Wood J, Lemieux PM, Betancourt D, Kariher P (2010) Dry thermal resistance of Bacillus Anthracis (Sterne) spores and spores of other Bacillus species: implications for biological agent destruction via waste incineration. J Appl Microbiol 109(1):99-106

Gładysz J, Grzesiak A, Nieradko-Iwanicka B, Borzęcki A (2010) The influence of air pollution on human health and life expectancy. Probl Hig Epidemiol 91(2):178-180 (in Polish)

Gołofit-Szymczak M, Górny RL (2017) Bioaerosols in office buildings. Kosmos 66(3):491-502 (in Polish)

Gołofit-Szymczak M, Ławniczek-Wałczyk A (2011) Biomass as a source of biological hazards. Bezpieczeństwo Pracy 12:17-19 (in Polish)

Gołofit-Szymczak M, Ławniczek-Wałczyk A, Górny RL (2013) Bioaerosols in indoor workplaces - hazards and their sources. Bezpieczeństwo Pracy 3:9-11 (in Polish)

Góra A, Skórska CZ, Sitkowska J, Prażmo Z, Krysińska-Traczyk E, Urbanowicz B, Dutkiewicz J (2004) Exposure of hop growers to bioaerosols. Ann Agric Environ Med 11:129-138

Górny RL (2004) Particles of fungi and bacteria as components of rooms aerosol: properties, emission mechanisms, detection. Institute of Occupational Medicine and Environmental Health, Sosnowiec (in Polish)

Górny RL (2010) Biological aerosols - a role of hygienic standards in the protection of environment and health. Med Środ 13:41-51 (in Polish)

Górny RL (2019) Microbial aerosols: sources, properties, health effects, exposure assessment - a review. Kona Powder Part J. https://doi.org/ 10.14356/kona.2020005

Górny RL, Dutkiewicz J (2002) Bacterial and fungal aerosols in indoor environment in Central and Eastern European. Ann Agric Environ Med 9:17-23

Gotkowska-Płachta A, Filipowska Z, Korzeniewska E, Janczukowicz W (2008) Microbiological contamination of atmospheric air in the constructed wetland (with aerated and stabilization ponds) and in its surrounding. Water Environ Rural Areas 1(22):83-93 (in Polish)

Grajewski J, Twarużek M (2004) Health aspects of mold and mycotoxin interaction. Alergia 3(21):45-49 (in Polish)

Grzyb J, Lenart-Boron A (2020) Size distribution and concentration of fungal aerosol in animal premises of a zoological garden. Aerobiologia 36:233-248. https://doi.org/10.1007/s10453-02009625-Z

Gutarowska B, Piotrowska M (2007) Methods of mycological analysis in buildings. Build Environ 42:1843-1850

Gwo-Hwa W, Chih-Shan L (1999) Indoor endotoxin and glucan in association with airway inflammation and systemic symptoms. Arch Environ Health 54:172

Han Y, Wang Y, Li L, Xu G, Liu J, Yang K (2018) Bacterial population and chemicals in bioaerosols from indoor environment: sludge dewatering houses in nine municipal wastewater treatment plants. Sci Total Environ 618:469-478

Helbling A, Reimers A (2003) Immunotherapy in fungal allergy. Curr Allergy Asthma Rep 3:447-453

Heo Y, Park J, Lim SI, Hur HG, Kim D, Park K (2010) Size-resolved culturable airborne bacteria sampled in rice field, sanitary landfill and waste incineration sites. J Environ Monit 12(8):1619-1624

Herbarth O, Schlink U, Müller A, Richter M (2003) Spatiotemporal distribution of airborne mould spores in apartments. Mycol Res 107: $1361-1371$

Jain AK (2000) Survey of bioaerosol in different indoor working environments in central India. Aerobiol 16(2):221-225
Jakubczyk E (1999) Hygienic requirements ensuring the production of dairy products of safe quality. Air management in a production environment. Przegląd Mleczarski 3:75-79 (in Polish)

Jiayu C, Qiaoqiao R, Feilong C, Chen L, Jiguo W, Zhendong W, Lingyun C, Liu R, Guoxia Z (2019) Microbiology community structure in bioaerosols and the respiratory diseases. J Environ Sci Public Health 3:347-357

Juszczak L (2011) What's hidden in food? Microbiological, environmental and technological hazards in food of plant origin. Agro Przem 5 (in Polish)

Kaiser K, Wolski A (2007) Control of microbiological air purity. Technika chłodnicza i klimatyzacyjna 4(134):158-162 (in Polish)

Kalogerakis N, Paschali D, Lekaditis V, Pantidou A, Eleftheriadis K, Lazaridis M (2005) Indoor air quality - bioaerosol measurements in domestic and office premises. J Aerosol Sci 36:751-761

Kim KH, Kabir E, Jahan SA (2018) Airborne bioaerosols and their impact on human health. J Environ Sci 67:23-35

Kołożyn-Krajewska D (2001) Hygiene of food production. SGGW, Warszawa (in Polish)

Kozdrój J, Frączek K, Ropek D (2019) Assessment of bioaerosols in indoor air of glasshouses located in a botanical garden. Build Environ 166:1-9

Krajewski JA, Tarkowski S, Cyprowski M (2000) Hazardous health effects in communal waste collection and disposal workers. Med $\mathrm{Pr}$ 51(2):159-172 (in Polish)

Krysińska-Traczyk E, Pande BN, Skórska CZ, Sitkowska J, Prażmo Z, Cholewa G, Dutkiewicz J (2005) Exposure of Indian agricultural workers to airborne microorganisms, dust and endotoxin during handling of various plant products. Ann Agric Environ Med 12: 268-275

Lai ACK, Tan TF, Li WS, Ip DKM (2018) Emission strength of airborne pathogens during toilet flushing. Indoor Air 28:73-79

Lang-Yona N, Shuster-Meiseles T, Mazar Y, Yarden O, Rudich Y (2016) Impact of urban air pollution on the allergenicity of Aspergillus fumigatus conidia: outdoor exposure study supported by laboratory experiments. Sci Total Environ 541:365-371

Ławer KM (2019) Microbiological air contamination in touristic atractiv places. Kosmos 68(3):429-441 (in Polish)

Ławniczek-Wałczyk A, Górny RL (2010) Endotoxins and $\beta$-glucans as markers of microbiological contamination - characteristics, detection and environmental exposure. Ann Agric Environ Med 17:193208

Li Y, Ge Y, Wu C, Guan D, Liu J, Wang F (2020) Assessment of culturable airborne bacteria of indoor environments in classrooms, dormitories and dining hall at university: a case study in China. Aerobiologia. https://doi.org/10.1007/s10453-020-09633-z

Małecka-Adamowicz M, Kubera Ł, Jankowiak E, Dembowska E (2019) Microbial diversity of bioaerosol inside sports facilities and antibiotic resistance of isolated Staphylococcus spp. Aerobiol 35:731-742

Mayer S, Twarużek M, Błajet-Kosicka A, Grajewski J (2016) Occupational exposure to mould and microbial metabolites during onion sorting - insights into an overlooked workplace. Environ Monit Assess 188:1-10

Mazurkiewicz-Zapałowicz K, Golianek A, Wolska M (2016) Allergenic fungi in bioaerosol. Kosmos 4(313):647-655 (in Polish)

Menetrez MY, Foarde KK, Dean TR, Betancourt DA (2010) The effectiveness of UV irradiation on vegetative bacteria and fungi surface contamination. Chem Eng J 157:443-450

Mirskaya E, Agranovski IE (2018) Sources and mechanisms of bioaerosol generation in occupational environments. Crit Rev Microbiol 44(6):739-758

Nguyen TT, Poh MK, Low J, Kalimuddin S, Thoon KC, Ng WC, Anderson BD, Gray GC (2017) Bioaerosol sampling in clinical settings: a promising, noninvasive approach for detecting respiratory viruses. Open Forum Infect Dis 4(1):259 
Nielsen BH, Nielsen EM, Breum NO (2000) Seasonal variation in biaerosol exposure during biowaste collection and measurements of leaked percolate. Waste Manag Res 18(1):64-72

Niemiec W, Zamorska J (2002) Municipal landfills and microbiological contamination of environment. Przeg Komunal 10(133):52-53 (in Polish)

Nourian AA, Badali H, Khodaveri M, Hamzehei H, Mohseni S (2007) Airborne mycoflora of Zanjan-Iran. Int J Agric Biol 9(4):628-630

Obtułowicz K (2001) Practical allergology. Medical PZWL, Warszawa (in Polish)

Pasanen AL, Kasanen JP (2000) Fungal growth and survival in building materials under fluctuating moisture and temperature conditions. Int Biodeterior Biodegrad 46:117-127

Paśmionka I (2020) Evaluation of microbiological quality of atmospheric air in a selected sewage treatment plant in Lesser Poland. Aerobiologia 36:249-260. https://doi.org/10.1007/s10453-02009627-x

Pastuszka JS, Paw UKT, Lis DO, Wlazło A, Ulfig K (2000) Bacterial and fungal aerosol in indoor environment in Upper Silesia. Atmos Environ 34:3833-3842

Patil P, Kamble R (2017) Occupational health hazards in municipal solid waste collecting workers of Chandrapur city, Central India. Int J Environ 6(1):46-57

Pillai SD, Ricke SC (2002) Bioaerosols from municipal and animal wastes: background and contemporary issues. Can J Microbiol 48(8):681-696

Piotrowska M, Żakowska Z, Gliścińska A, Bogusławska-Kozłowska J (2001) The role of outdoor air microflora in forming fungal bioaerosol in closed rooms. In: Distribution and Microbiological Corrosion of Technical Materials. Politechnika Łódzka, Łódź, pp 113-122 (in Polish)

Polymenakou PN (2012) Atmosphere: a source of pathogenic or beneficial microbes? Atmosphere 3(1):87-102

Prażak Z, Kowalska M (2017) Biological factors in occupational environment of nurses and possibilities of reducing exposure. Hyg Publ Health 52(2):111-118 (in Polish)

Prussin AJ, Garcia EB, Marr LC (2015) Total concentrations of virus and bacteria in indoor and outdoor air. Environ Sci Technol Lett 2:84-88

Puspita ID, Kamagata Y, Tanaka M, Asano K, Nakatsu CH (2012) Are uncultivated bacteria really uncultivable? Microbes Environ 27(4): 356-366

Rajput P, Anjum MH, Gupta T (2017) One year record of bioaerosols and particles concentration in Indo-Gangetic Plain: implications of biomass burning emissions to high-level of endotoxin exposure. Environ Pollut 224:98-106

Redford AJ, Fierer N (2009) Bacterial succession on the leaf surface: a novel system for studying successional dynamics. Microb Ecol 58(1):189-198

Reeb-Whitaker CK, Bonauto DK (2014) Respiratory disease associated with occupational inhalation to hop (Humulus lupulus) during harvest and processing. Ann Allergy Asthma Immunol 113:534-538

Robertson S, Douglas P, Jarvis D, Marczylo E (2019) Bioaerosol exposure from composting facilities and health outcomes in workers and in the community: a systematic review update. Int J Hyg Environ Health 222(3):364-386

Roy CJ, Reed DS (2012) Infectious disease aerobiology: miasma incarnate. Front Cell Infect Microbiol 2:163

Salonen H, Duchaine C, Létourneau V, Mazaheri M, Laitinen S, Clifford S, Mikkola R, Lappalainen S, Reijula K, Morawska L (2016) Endotoxin levels and contribution factors of endotoxins in resident, school, and office environments - a review. Atmos Environ 142: 360-369

Simon X, Duquenne P (2014) Assessment of workers' exposure to bioaerosols in a French cheese factory. Ann Occup Hyg 58:677-692

Skórska CZ, Golec M, Mackiewicz B, Góra A, Dutkiewicz J (2005) Health effects of exposure to herb dust in valerian growing farmers. Ann Agric Environ Med 12:247-252

Soroka PM, Cyprowski M, Szadkowska-Stańczyk I (2008) Occupational exposure to mycotoxins in various branches of industry. Med Pr 59(4):333-345 (in Polish)

Stryjakowska-Sekulska M, Piotraszewska-Pajak A, Szyszka A, Nowicki M, Filipiak M (2007) Microbiological quality of indoor air in university rooms. Pol J Environ Stud 16:623-632

Sykes P, Jones K, Wildsmith JD (2007) Managing the potential public health risks from bioaerosol liberation at commercial composting sites in the UK: an analysis of the evidence base. Resour Conserv Recycl 52:410-424

Tsapko VG, Chudnovets AJ, Sterenbogen MJ, Papach VV, Dutkiewicz J, Skórska CZ, Walser MS, Gerstner DG, Brenner B, Bunger J, Eikmann T, Janssen B, Kolb S, Kolk A, Nowak D, Raulf M, Sagunski H, Sedlmaier N, Suchenwirth R, Wiesmuller G, Wollin K-M, Tesseraux I, Herr CEW (2015) Evaluation of exposure - response relationships for health effects of microbial bioaerosols - a systematic review. Int J Hyg Enviorn Health 218:577-589

Vantarakis A, Paparrodopoulos S, Kokki-Nos P, Vantarakis G, Fragou K, Detorakis I (2016) Impact on the quality of life when living close to a municipal wastewater treatment plant. J Environ Public Health 2016:1-8. https://doi.org/10.1155/2016/8467023

Walser MS, Gerstner DG, Brenner B, Bunger J, Eikmann T, Janssen B, Kolb S, Kolk A, Nowak D, Raulf M, Sagunski H, Sedlmaier N, Suchenwirth R, Wiesmuller G, Wollin K-M, Tesseraux I, Herr CEW (2015) Evaluation of exposure - response relationships for health effects of microbial bioaerosols - A systematic review. Inter J Hyg Enviorn Health 218:577-589

Wei M, Xu C, Xu X, Zhu C, Li J, Lv G (2019) Size distribution of bioaerosols from biomass burning emissions: characteristics of bacterial and fungal communities in submicron (PM1.0) and fine (PM2.5) particles. Ecotoxicol Environ Saf 171:37-46

Wołejko E, Kowaluk-Krupa A, Wydro U, Butarewicz A, JabłońskaTrypuć A, Piekut J, Dec D, Łoboda T (2016) The assessment of microbiological indoor air quality in bakeries. Inż Ekol 47:182188 (in Polish)

Ziajka S (2008) Dairying. UWM, Olsztyn (in Polish)

Publisher's note Springer Nature remains neutral with regard to jurisdictional claims in published maps and institutional affiliations. 